\title{
RESENHAS
}

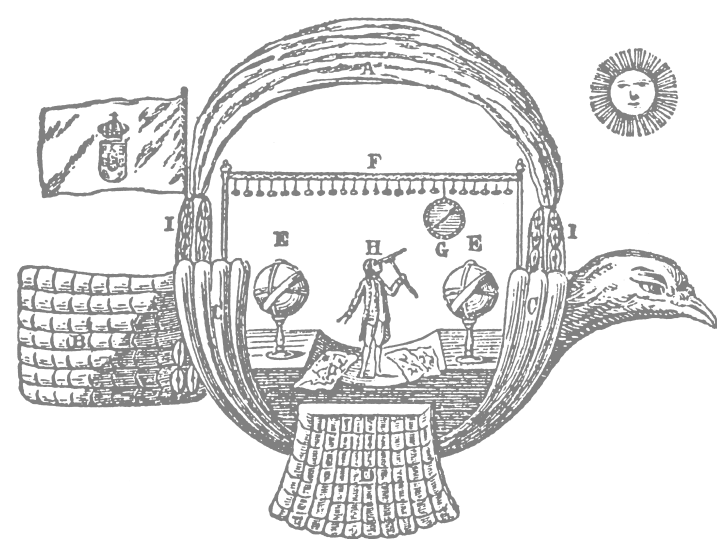





\section{O OLHAR CRÍTICO DE MARIA APARECIDA SANTILLI EM PARALELAS E TANGENTES ENTRE LITERATURAS DE LÍNGUA PORTUGUESA}

Benilde Justo Caniato

Universidade de São Paulo

I

ntegrando 20 artigos, esta obra de Maria Aparecida Santilli foi produzida em momentos diferentes de sua atividade profissional, na Área de

Letras. Refletindo sobre a língua e a literatura de África, Brasil e Portugal, a Autora assinala pontos que correm em paralela na mesma direção e outros que tangenciam em determinados encontros. Abarcam tempos, que vão desde os descobrimentos iniciados no século $\mathrm{XV}$, a determinar a expansão da língua e da cultura portuguesa, até o século XX, "século privilegiado da descolonização, da queda dos imperialismos ao velho estilo europeu".

Centro catalisador de cultura em oito países, a língua portuguesa subsiste, ainda que com realidades lingüísticas diferenciadas, em face das variantes geradas no processo dinâmico de seu uso. Voltando seu olhar para os oito países da CPLP, a Professora Santilli sublinha a função estruturante da língua como comunicação e como codificação estética e ideológica. A literatura, por sua vez, reincidirá no plano individual visando ao auto-reconhecimento e no plano social, abrindo-se para a alteridade. Assim, a circulação interna e a permuta de obras literárias levará, certamente, cada um a conhecer as suas peculiaridades e as dos outros, "um saber para estreitar os laços no círculo da CPLP”.

As navegações conduziram a migrações não só de povos, mas também de motivos literários, como acentua a Professora. Assim, um dos motivos itinerantes, a partir da literatura brasileira para a portuguesa e africana, foi a Pasárgada, de Manuel Bandeira. Apologia da outridade, no dizer da Autora, a construir um mundo imaginário, ilustrada pelos poetas portugue- 
ses da Távola Redonda e por textos em prosa de David Mourão Ferreira e Luiz de Macedo, a Pasárgada do nosso poeta, "paradigma de conquista última pelo homem, surge como território ideal ou como cidade eterna”. A emigração do poeta cabo-verdiano Baltasar Lopes igualmente faz pouso na Pasárgada, com cinco poemas, nos quais se manifesta o desejo de um futuro que possa levar à redenção. A leitura “com” Manuel Bandeira, “de franca adesão, de comprazer-se na fruição do lugar ameno”, acaba por seduzir o poeta do Verde Arquipélago à evasão, tão comum nos textos literários dos mentores de Claridade.

No mesmo patamar tangencial encontram-se Guimarães Rosa e Luandino Vieira, criadores de linguagens, consagrados contistas de cá e de lá do Atlântico. Como diria Luandino Vieira, em entrevista a Michel Laban, o instrumento lingüístico deve ser no plano da criação. Enquanto Luandino reflete, em sua linguagem, situações do quotidiano, privilegiando o espaço sociocultural dos musseques de Luanda, Guimarães Rosa utiliza-se das inúmeras possibilidades da língua, privilegiando a do sertão de Minas Gerais. Ambos, ao romper com a norma, renovam usos lingüísticos, elevando as possibilidades do sistema da língua portuguesa.

Se até princípios do século XIX, os escritores brasileiros estribavam-se no modelo do português europeu, seguindo-lhe as normas gramaticais, mantendo unificada a língua culta, os movimentos literários que se seguem ao Romantismo mostram o descompasso entre portugueses e brasileiros das primeiras décadas do século XX, “aspiração que passou pela literatura nos topoi da identidade pessoal ou nacional". Na Semana da Arte Moderna de 1922, "re-ver" e "re-buscar uma identidade" destacou-se como prioridade, acentuando-se uma declarada rebeldia ao casticismo peninsular. Buscando re-inventar os sentidos para designar nossa identidade, alguns modernistas optaram pela via alegre do riso, segundo Maria Aparecida Santilli. Citando o poema "brasil” de Oswald de Andrade que, rindo, "põe em xeque/choque a decantada trindade étnica nacional", salienta ser o texto do nosso modernista aspiração a "uma perspectiva poética própria, transatlântica”. E os acontecimentos históricos acabam por ser metabolizados pela consciência nacional, na medida em que o poeta assume antropofagicamente nosso passado.

Em "Fronteiras da liberdade, na ficção das Literaturas de Língua Portuguesa”, a Professora seleciona obras em que há quebra do canon mais 
convencional da prosa de ficção, isto é, aquelas em que o narrador de primeira pessoa substitui o de terceira pessoa. Sabe-se que o romancista, ao construir suas personagens, parte de elementos de sua vida pessoal, sendo elas máscaras pelas quais ele conta, utilizando-se de sua própria memória, como diz Butor, citado pela Autora. Assim, o romance Mayombe é apresentado em Paralelas e tangentes sob a égide das pessoas gramaticais. Destaca-se o efeito da heteronímia, uma vez que, no corpo da narrativa de terceira pessoa, o narrador encaixa a primeira, assumindo de alguma maneira $o$ relato, mesmo quando o texto está na terceira pessoa. Multiplica-se o eu, provocando um exercício de interatividade explícita ou até programática entre emissores e receptores. As pessoas gramaticais acabam por perder a rigidez que habitualmente há nos romances, pois, nesta obra de Pepetela, elas estão em permanente comunicação.

Outros exemplos arrolados pela Professora Santilli são os das Novas cartas portuguesas, as cartas das três Marias que, quando tratam do tema da liberação da mulher, procuram, no tecido epistolográfico, revelar a imagem da mulher do século XX. Assim, o eu das autoras acaba também por projetar-se no mundo literário como uma forma de "proclamação de liberdade na arte da escrita feminina".

Ao tratar dos anos 40, na ficção portuguesa e brasileira, a Autora destaca a imagem dos desprivilegiados da sociedade, representados pelos trabalhadores braçais, como o fez Alves Redol, em Gaibéus, testemunhando historicamente a vida dos ceifeiros do Ribatejo. O documento como registro, o testemunho e o comentário como transposição crítica da realidade intensificam a função referencial do discurso. Carlos de Oliveira, Vergílio Ferreira, Cardoso Pires inscrevem-se também no Neo-Realismo, registrando o apego à terra, que se respalda em práticas ancestrais da vida pastoril ou agrária.

Vidas secas enquadra-se nas obras regionalistas, mas num realismo crítico, pois o herói não aceita o mundo, nem os outros, nem a si mesmo, é o que diz a Professora, citando Alfredo Bosi. Entre esta obra de Graciliano Ramos e a de Alves Redol, ambas livros de quadros, conforme a Autora, as aproximações em relação ao imaginário da terra são evidentes, mas em relação às personagens se notam diferenças, na medida em que em Gaibéus o herói pertence à coletividade. 
A Professora Santilli quer, principalmente, sinalizar que as propostas literárias dos anos 40 não podem taxar-se como passado morto. Saramago e Antônio Callado, autores consagrados dos tempos atuais, bem demonstram que a linha literária maturou e frutificou, co-apropriando-se do fato real, textualizado tanto pela história quanto pela ficção.

Os textos de Paralelas e tangentes, muitos deles na linha de estudos comparados, acabam por constituir um olhar agudo e crítico da Autora, singularizando seu compromisso de estudiosa das literaturas de Portugal, Brasil e África. Convidando seus leitores a terem acesso a textos que exploram diversificados níveis, como o histórico, cultural, social ou político, Maria Aparecida Santilli repassa suas reflexões sobre a língua e a literatura de países da CPLP, cujas respostas foi buscá-las "no caminho de dilatar o entendimento do mundo, pela mediação de outros que imaginações privilegiadas foram capazes de conceber". 